\title{
COLHER MEMÓRIAS DE VELHOS: RETRATOS DE AVÓS EM OBRAS DO CARIBE FRANCÓFONO
}

\author{
Spooning old memories: portraits of grandparents in francophone Caribbean works
}

\author{
Vanessa Massoni da Rocha \\ https://orcid.org/0000-0003-2940-7931 (c) \\ Universidade Federal Fluminense, Instituto de Letras, Niterói, \\ RJ, Brasil. 24210-200 -gle.egl@id.uff.br
}

Resumo: Este artigo se propõe a perscrutar representações da velhice a partir do imaginário de avós em textos teórico-literários redigidos por seus netos e netas após o falecimento dos progenitores. Com o envelhecimento acentuado de diversas populações, torna-se urgente revisitar o paradigma desta fase da vida como etapa de declínio, propícia à doença, ao enfraquecimento e à inevitável morte. Partindo-se do conceito de "valor refúgio" proposto pelo crítico literário tunisiano Albert Memmi e no intuito de 'colher memórias de velhos', como o fez a escritora e psicóloga brasileira Éclea Bosi, nossas análises se debruçam nas relações familiares e na importância da ancestralidade no seio da sociedade em obras do caribe francófono, mais precisamente da ilha de Martinica e do arquipélago de Guadalupe. Neste sentido, acolhemos notadamente textos dos martinicanos Patrick Chamoiseau, Raphaël Confiant, Fabienne Kanor e dos guadalupenses Simone Schwarz-Bart, Maryse Condé e Dominique Lancastre nos quais estão em cena a relação entre velhice e representação literária e nos quais emergem as noções de "oralitura" (CHAMOISEAU, 2002), "busca identitária" (CHAMOISEAU, 2016) "presentificação" (FOUCAULT, 1992), "fabulação" (HUSTON, 2008) e morte como "ausência" (CHAMOISEAU, 2016). Por fim, vislumbra-se a ancestralidade e sua importância a partir da metáfora da árvore (HAMPÂTÉ BÂ), do "húmus" (KANOR, 2006) e da "seiva" (BOSI, 2003) para dar a ver um corpo social marcado pelos ensinamentos, pelas insurgências e pelo altruísmo de avós "velhos demais para morrer" (MARIANO, 2020).

Palavras-chave: Velhice. Memória de velhos. Avós. Morte e escrita. Literatura caribenha.

Abstract: This article aims to examine representations of old age from the imaginary of grandparents in theoretical-literary texts written by their grandchildren after the death of their parents. With the marked aging of diverse populations, it is urgent to revisit the paradigm of this phase of life as a stage of decline, conducive to disease, weakness and the inevitable death. Based on the concept of "refuge value" proposed by the Tunisian literary critic Albert Memmi and in order to "collect memories from old people', as Brazilian writer and psychologist Éclea Bosi did, our analyzes focus on family relationships and the importance of ancestry within society in works in the French-speaking Caribbean, more precisely on the island of Martinique and the archipelago of Guadalupe. In this sense, we particularly welcome texts by Martinicans Patrick Chamoiseau, Raphaël Confiant, Fabienne Kanor and Guadeloupe Simone Schwarz-Bart, Maryse Condé and Dominique Lancastre in which the relationship between old age and literary representation is on the scene and the notions of "oralitura" (CHAMOISEAU, 2002), "identity search" (CHAMOISEAU, 2016) "presentification" (FOUCAULT, 1992), "fabulation" (HUSTON, 2008) and death as "absence" (CHAMOISEAU, 2016). Finally, ancestry and its importance are glimpsed from the metaphor of the tree (HAMPÂTÉ BÂ), the "humus" (KANOR, 2006) and the "sap" (BOSI, 2003) to show a social body marked by teachings, insurgencies and altruism of grandparents "too old to die" (MARIANO, 2020). 
Keywords: Old age. Old people's memory. Grandparents. Death and writing. Caribbean literature.

Daí que também a vó me ensinou a não desprezar as coisas

desprezíveis

E nem os seres desprezados.

Manoel de Barros (2018, p. 18)

Este artigo toma como ponto de partida as considerações do crítico literário João Alexandre Barbosa (1979), segundo as quais "em nossa sociedade de classes, dilacerada até as raízes pelas mais cruéis contradições, a mulher, a criança e o velho são, por assim dizer, instâncias privilegiadas daquelas crueldades - traduções do dilaceramento e da culpa" (1979, p. XI) para cartografar representações sobre os mais velhos em obras teóricoliterárias do Caribe $^{1}$ francófono, mais precisamente da ilha de Martinica e do arquipélago de Guadalupe. Para tal, acolhemos a definição da escritora e filósofa Marilena Chauí (1979), para quem os idosos "são a fonte de onde jorra a essência da cultura, ponto onde o passado se conserva e o presente se prepara, pois, como escrevera Benjamin, só perde o sentido aquilo que no presente não é percebido como visado pelo passado" (1979, p. XVIII).

Cientes de que "o envelhecimento e a velhice têm sido, até recentemente, categorias invisíveis, praticamente desconhecidas tanto ao nível da crítica literária, como em todas as demais disciplinas das Humanidades" (DODMAN, 2015, p. 120) e de que "a velhice tende a ser vista apenas como etapa final, fase de declínio, propícia à doença, ao enfraquecimento e à inevitável morte" (DODMAN, 2015, p. 120), buscamos neste artigo observar como a tessitura antilhana acolhe a representação dos mais velhos feita a partir de seus netos e netas para dar a ver um mosaico da velhice, das relações familiares e da importância da ancestralidade no seio da sociedade.

A perspectiva que adotamos é de um olhar que se volta para o passado e que brinca com a função de tudo rememorar, amplamente atrelada à velhice. Jogando com o preceito de que "a função social do velho é lembrar e aconselhar - memini, moneo - unir o começo e o fim, ligando o que foi e o por vir" (CHAUÍ, 1979, p. XVIIII), neste estudo, os mais velhos se tornam o alvo por detrás das lentes de netos e netas que perscrutam seus ensinamentos, seus gestos, suas maneiras de sorrir, de chorar, de enfrentar dilemas, de comemorar vitórias e de lamentar insucessos. Neste sentido, percebe-se um olhar para trás que se imprime na realidade dos narradores, preenchendo um presente e projetando um futuro capaz de povoar ausências e prologar presenças, por intermédio de mecanismos ficcionais.

$\mathrm{Na}$ contramão de discursos insensíveis - e perversos - que apontam para o fardo da

\footnotetext{
1 É recorrente o termo Antilhas para se referir ao Caribe. Há as Grandes Antilhas, a saber: Cuba, Jamaica, Porto Rico, Haiti, República Dominicana e Ilha da Juventude e as Pequenas Antilhas, uma série de ilhas que se estendem em um arco desde Porto Rico até o norte da América do Sul. Integram as Pequenas Antilhas alguns departamentos e territórios franceses, como Martinica, Saint-Barthélemy e Saint-Martin (uma parte da ilha é francesa e outra é holandesa) e o arquipélago de Guadalupe.
} 
velhice e para o fato de os mais velhos se tornarem estorvos para a família e para a sociedade, privilegiamos textos-elogios aos progenitores, textos-afetos que rememoram suas ações e evidenciam suas lições. Em outras palavras, textos que se atém à importância destes entes como esteios da família, não se furtando a aconselhar e aconchegar os que os cercam. Cabe observar que nos textos acolhidos, os avós já tinham falecido quando os netos e netas se dedicam à escrita, o que imprime em seus textos o desejo de prolongar uma conversa e de rememorar vidas que não se deixam esquecer.

Em uma sociedade capitalista neoliberal cuja única preocupação parece ser a força de trabalho e o vigor para produzir, gerar lucros e movimentar a roda da fortuna de uns a partir da exploração de outros, não tardamos para observar uma velhice, em grande parte, "oprimida, despojada e banida" (CHAUÍ, 1979, p. XVIII), que se encontra fragilizada, com parcos recursos e vive às expensas dos herdeiros. Se, por um lado, há a falácia da improdutividade e da vida dos mais velhos como peso sobressalente para as contas públicas, por outro, nesta espiral cruel, impõe-se o dado de uma sociedade que envelhece cada vez mais e expõe as vísceras de uma engrenagem político-econômica-social dissociada da realidade.

A este respeito, a economista Marcelle Jeanne-Rose (2016) se debruça na sociedade caribenha e afirma que "o envelhecimento está se intensificando e as Antilhas estão dentre as regiões com maior número de idosos na França"” (2016, p. 1). Eis os dados que a pesquisadora apresenta: "Em 2014, 92.180 pessoas com 60 anos ou mais, residem na Martinica. Em 2032, o número de pessoas com 60 anos ou mais será maior do que aquelas com menos de 60 anos" (JEANNE-ROSE, 2016, p. 1). Diante desta projeção, Jeanne-Rose se apressa em explicar que o envelhecimento da população martinicana se deve principalmente "a um déficit de migração juvenil estruturalmente alto. Este déficit resulta da partida de uma parte importante desta população em idade fértil para a busca de estudos ou emprego" (2016, p. 1).

Logo, os versos do poeta brasileiro Manoel de Barros (2018) que acolhemos como epígrafe deste artigo se mostram norteadores para as reflexões empreendidas. Intitulado de "Obrar", o poema, de 2003, parte do elogio da transgressão da avó, grande lição transmitida ao eu-lírico, para aterrissar no ensinamento final de que não podemos desprezar as coisas desprezíveis nem os seres desprezados. O contexto do poema reflete o espaço da plantação e, numa primeira acepção, o desprezo se refere aos estrumes colocados nas roseiras e que se tornam responsáveis por sua revitalização, como se vê nos versos "A vó então quis aproveitar o feito para ensinar que o cago não é uma coisa desprezível" (BARROS, 2018, p. 18). Mais adiante, a avó elogia as mariposas e ressalta que nada deve ser depreciado na natureza. E aqui ampliamos a noção do poema e o associamos aos mais velhos, lembrando que "eu tinha vontade de rir porque a vó contrariava os ensinos do pai” (2018, p. 18). De fato, a avó estava atenta à função de cada

\footnotetext{
${ }^{2}$ São de minha autoria a tradução para o português de textos teóricos, literários e entrevistas referenciados em francês.
} 
ser, de cada coisa para o equilíbrio e a ordem do jardim, da vida, dos ciclos, por mais imperceptíveis e supostamente indispensáveis que pudessem parecer diante de olhos desaprendidos de olhar para além das aparências. E deduzimos que justamente por serem desprezados, os mais velhos, alvos de crueldades diversas, como já denunciou João Alexandre Barbosa (1979), devam ser acolhidos, retratados, observados através de filtros de afeto e de reconhecimento. O poeta, sob esta perspectiva, subverte o desapreço e aposta seu lirismo na ação de obrar, verbo que significa para além de "defecar", "exercer um ofício; realizar uma ação; trabalhar, agir". Deste modo, se reitera no poema a ode ao papel de todos e de cada um para a engrenagem da vida, todos obrando dentro de suas diversas possibilidades.

Espaços marcados pela violência da empreitada colonial francesa (1635-1946), do imperialismo "civilizatório" e da escravização, as Antilhas experienciaram dores atrozes que se imprimiram na tentativa de "apagamento imposto" (CHAMOISEAU, 2016, p. 46) da ancestralidade, no estilhaçamento de famílias e nas obliterações das origens. Como ocorreu em demais lugares do continente americano espoliados pelas navegações europeias nos séculos XV e XVI, as ilhas precisaram se recriar a partir de muito pouco e acalentar este muito pouco para transformá-lo em imaginário, em legado e em dote. Espaço de "transplantados" (GLISSANT, 2012, p. 175) marcados pelas reiteradas "depossessões" (GLISSANT, 2012, p. 95), futuros martinicanos e guadalupenses transformaram o quasenada que possuíam a partir dos "rastros" (GLISSANT, 2012, p. 276), compondo, de partida, uma árvore genealógica com poucos galhos conhecidos. Uma árvore, contudo, disposta a dar frutos e se tornar, na alquimia do tempo, frondosa e digna de orgulho.

O escritor malinês Amadou Hampâté Bâ, a quem se atribuiu a máxima lapidar "na África, quando um ancião morre, uma biblioteca se queima”, utiliza-se da metáfora da árvore para demonstrar a constituição das genealogias em sua célebre Carta para a juventude:

A vida humana é como uma grande árvore, e cada geração é como um
jardineiro. O bom jardineiro não é aquele que desenraiza, mas aquele que,
quando chega a hora, sabe como podar os galhos mortos e, se necessário,
prosseguir criteriosamente com enxertos benéficos. Cortar o tronco seria
cometer suicídio, renunciar à própria personalidade e artificialmente assumir
a de outras pessoas, sem nunca conseguir isso de forma completa. Mais
uma vez, vamos nos lembrar do velho ditado: A tora de madeira passou
muito tempo na água - ela pode flutuar, mas nunca se transformará em um
crocodilo! (apud WABERI, 2018, n.p)

Esta menção de Hampâté Bâ enfatiza os vínculos familiares e a importância dos ancestrais na formação de todos, rechaçando quaisquer falácias que apostem em autoengendramento e autossuficiência, dois motes que pairam sobre determinadas sociedades contemporâneas. A imagem do escritor malinês encontra eco em estudos da psicóloga e escritora Éclea Bosi (2003), para quem "a memória escolhe lugares privilegiados de onde tira sua seiva" (2003, p. 71$)$. Em ambos se reitera o postulado de um corpo social 
comparável a uma árvore, cujos frutos, folhas e galhos que caem ao solo se transformam em húmus e são recuperados pela planta, em um ciclo vital de transformação e de reapropriação. A imagem do húmus foi explorada pela escritora e cineasta martinicana Fabienne Kanor (2006) em romance homônimo sobre o tráfico negreiro e as viagens em tumbeiro. Nele, ao rememorar as mortes durante a travessia transatlântica, uma personagem pondera: "Estas mortas não estão mortas, elas nos assombram" (2006, p. 111). Em outro romance, D'eaux douces, de 2004, Fabienne Kanor identifica uma de suas progenitoras dentre as vítimas do "crime humanitário" (TAUBIRA, 2015, p. 75) do tráfico negreiro: "a bisavó de minha mãe está no mar, nos porões sujos e fedidos de um barco" (KANOR, 2004, p. 191). Assim, os textos insistem no fato de que o passado não ficou esquecido e de que as famílias tanto se ressentem pela perda de seus ancestrais quanto lamentam por famílias apartadas, implodidas, impedidas de se formar, "de extraordinárias possibilidades suprimidas" (CÉSAIRE, 2017, p. 32).

E o campo das manifestações artísticas não tardará a acolher estas feridas abertas: "não saber tudo permite aos herdeiros que somos de reinventar a história, preencher lacunas com nossos recursos (artísticos, políticos). [...] Se soubéssemos de tudo, esta memória sem dúvida acabaria por nos asfixiar, sua dor nos manteria num terreno ressentimento" (HERBECK, 2013, p. 975). Sob esta perspectiva,

cabe lembrar que a memória geracional pode ser transmitida de uma geração à outra (intergeracional), podendo ir além dos ancestrais terrenos (pai/mãe, avô/avó), considerando-se também os Patriarcas, ou seja, a liderança espiritual cuja aceitação ou não, em algumas circunstâncias, é fundamental para que haja continuidade ou ruptura. Nesse caso, trata-se de transmissão transgeracional. (BERND; SOARES, 2016, p. 408).

A imagem da árvore nos remete, ainda, à árvore do esquecimento localizada na cidade de Ouidah, no Benim, mais conhecido porto escravagista da costa oeste africana. Conta a tradição que os escravizados acorrentados eram obrigados a dar voltas na referida árvore, sete voltas os homens e nove, as mulheres, antes de serem embarcados nos navios negreiros para o transporte transatlântico. O simbolismo do ritual em torno da "árvore fetiche" (KANOR, 2006, p. 100) insistia no imperativo de rasura da cultura para mais fácil implementação da ordem imperialista e do vilipêndio identitário, em suas mais diversas manifestações.

No âmbito antilhano, "era preciso vencer o apagamento original. Reduzir a amputação [...] não somente assumir a falta, mas torná-la um imenso horizonte" (CHAMOISEAU, 2016, p. 51, grifo do autor) e, assim, os vestígios, as transmissões orais e a "oralitura" (CHAMOISEAU, 2002, p. 153) se encarregam de fazer germinar o pouco do que se lembra, encorpando-o num caldeirão de imaginações e aproximações. Nesta perspectiva,

os velhos dirão a África aos jovens. Por reminiscências pessoais, eles farão conhecer os esplendores do reino perdido, a glória dos heróis, a familiaridade do solo ancestral, a antiga dor de viver. Eles ensinarão a sabedoria através de contos, fábulas e provérbios (JUMINER, 2002, p. 138- 
139, grifo do autor).

Édouard Glissant, ao se ater ao trabalho de "busca identitária" (CHAMOISEAU, 2016, p. 51), preconiza que "temos de ser historiadores poéticos, devemos reinventar a periodização da história por adivinhação poética" (apud DAMATO, 1995, p. 190). Acreditamos que parte desta árvore genealógica que se constrói no novo continente beba igualmente da fonte da adivinhação poética, da "fabulação", tal como foi analisada por Nancy Huston (2010) no ensaio A espécie fabuladora, de 2008. Para a escritora canadense, "você cria a ficção da sua vida" (2010, p. 24) e "a especificidade da nossa espécie é que ela passa a vida toda representando a sua vida" (2010, p. 114).

No que tange à contação de histórias, Raphaël Confiant (1998) distingue dois lugares de circulação do conto, sendo o primeiro, "o interior - família - espaço privado onde todos os membros da família puderam se revezar para contar histórias, fazer perguntas ou contar piadas" (1998, p. 10) e o segundo, o exterior, sobretudo durante as vigílias fúnebres. A este respeito, o romance La Véranda (A Varanda), do guadalupense Dominique Lancastre (2010), se inscreve num elogio à família e às reuniões noturnas na varanda da casa para o compartilhamento de histórias. Eis como o tio René explicava a origem de suas narrativas: "Minha mãe, Lucienne, a escutou da boca da minha avó, Émilia, que escutou da boca da mãe de sua avó enquanto ela cortava e recolhia a cana-de-açúcar nas plantações dos Brancos" (LANCASTRE, 2014, p. 38). E assim, a tessitura dos contos retoma a tessitura familiar, a voz dos ausentes e o elogio dos ancestrais. Neste universo da oralidade crioula, o passado reinstaura no presente uma ausência presentificada em lembranças compartilhadas e reaquecidas no seio da família.

Em seu romance de estreia La Véranda, em 2010, laureado com o Prix Bal de Paris du roman d'Outre-mer (Prêmio Baile de Paris do romance ultramarino), Lancastre cartografa a infância de um menino no arquipélago caribenho e compõe uma obra de formação. O autor coloca em xeque a escola colonial "cujas imagens dos métodos não correspondia em nada à cor da turma" (2011, p. 30) e declara que "vinda a noite, a varanda iria restabelecer a verdade onde os Negros quilombolas e os tambores falantes iam me ninar, me fazer rir, me assustar até de manhãzinha" (2011, p. 30). Por fim, o narrador questiona sua professora, Madame Duverger e as violências reiteradas do colonialismo: "Teria ela compreendido verdadeiramente o sentido das histórias da varanda onde eu me enriquecia cada noite, de noite, de uma cultura da qual queriam a todo preço me distanciar?" (2011, p. 30).

O escritor e ensaísta tunisiano Albert Memmi (2007), ao estudar os mecanismos da colonização e seus efeitos, define a família como um "valor refúgio" (2007, p. 141) indispensável para os seres (pós)colonizados. Como explicita o conceito, a família encarnaria o lugar-refúgio, lugar-proteção, lugar-abrigo em meio às intempéries. Por certo, em torno deste núcleo marcado geralmente pela afetividade, pelo acolhimento e pela proteção se tecem forças capazes de suportar as mazelas quotidianas. Para além disto, o elo familiar aponta para o coletivo, para a genealogia, as origens, os ancestrais. No âmbito 
da representação literária, emerge a ideia de que "a escrita é, às vezes, uma reveladora do Invisível" (CONFIANT, 2012, p. 173). De fato, "se a palavra, herdeira de uma África perdida para sempre, possui o dom de domar a morte e torná-la assim um pouco suportável, ao contrário, somente o livro pode pretender explicar seus noventa mistérios" (CONFIANT, 2012, p. 11). Assim, as dimensões da escrita se descortinam em sua vocação para prolongar vidas, ludibriar mortes, manter/reaquecer vínculos familiares e, em outras palavras, encenar em sua tessitura ausências e presenças.

Partindo-se da premissa do valor refúgio, é preciso ressaltar a omnipresença da representação familiar na literatura antilhana de expressão francesa. A título de exemplificação, sagas familiares foram acolhidas pelos martinicanos Édouard Glissant, Patrick Chamoiseau e Raphaël Confiant. Em Le quatrième siècle (1964), Édouard Glissant acompanha duas famílias entre 1788 e 1946, perscrutando os rumos dos seres escravizados que foram para as fazendas (família Béluse) ou se refugiaram nos quilombos (família Longoué) e de seus herdeiros. Em Texaco ${ }^{3}$ (1992), laureado com o Prêmio Goncourt, Patrick Chamoiseau toma como ponto de partida os cadernos escritos por MarieSophie Laborieux a partir de narrativas centradas em seus pais, avós, bisavós para retraçar 150 anos da história martinicana, desde a empreitada colonial francesa, passando pela escravização e a construção da cidade. Raphaël Confiant se dedica a acompanhar a família Saint-Albert na saga Les Saint-Albert por meio de romances que observam Ferdinand, Marie-Élodie e seus quatro filhos ao longo do século XX em recortes temporais de 20 em 20 anos. Os dramas da família se confundem com grandes vultos históricos da história da Martinica, como a erupção do vulcão da Montanha Pelée em 1902, a participação antilhana na Primeira Guerra Mundial, a grande greve agrícola de 1935 e as celebrações do tricentenário de relação entre a Martinica e a França metropolitana. O projeto de enorme fôlego prevê cinco romances. Até o momento, foram publicados dois deles: L'en-allée du siècle, 1900-1920, em 2012 e Les trente-douze mille douleurs, em 2014.

Em Guadalupe, podemos mencionar a saga familiar reconstituída por Maryse Condé para contar o declínio do Reino africano de Bambara, cuja capital é Ségou, a partir das dores de Dousika Traoé com o destino de seus quatro descendentes. Trata-se das obras Ségou: Les murailles de terre [As muralhas da terra], em 1984 e Ségou: La terre en miettes [A terra em migalhas], no ano seguinte. Simone Schwarz-Bart, por sua vez, dedica Pluie et vent sur Télumée Miracle ( $A$ ilha da chuva e do vento), de 1972, a quatro gerações da linhagem Lougandor, além de desenvolver a quatro mãos com o marido André SchwarzBart a empreitada literária em torno da escravizada Solitude e de suas herdeiras, percurso desenvolvido nas obras Un plat de porc aux bananes vertes [Um prato de porco com bananas verdes] (1967), L'ancêtre en Solitude [A ancestralidade em Solitude] (2015) e Adieu Bogota [Adeus Bogotá] (2017) em torno das personagens Bayangumay, Solitude,

\footnotetext{
${ }^{3} \mathrm{O}$ romance Le quatrième siècle, de Glissant, foi traduzido em português por Cleone Augusto Rodrigues como O quarto século e publicado em 1986. Texaco, de Chamoiseau, ganhou versão homônima em português na tradução de Rosa Freire d'Aguiar, em 1993.
} 
Louise, Hortensia e Mariotte.

Logo, quer seja por histórias diluídas em diversos tomos, quer seja em histórias inscritas em uma única obra, fato é que a ficção antilhana não prescinde da família. Muito pelo contrário. É através dela que se delineiam os dramas ligados à história, à língua, ao espaço e aos mais diversos conflitos dos personagens. No manifesto da crioulidade Éloge de la créolité, a tríade martinicana Jean Bernabé, Patrick Chamoiseau e Raphaël Confiant estudava, dentre outros temas, a relação entre a literatura e a visão interior da identidade antilhana. Nesta obra bilíngue publicada em 1989, os intelectuais preconizavam que "não pode existir uma verdadeira abertura sobre o mundo sem uma apreensão anterior e absoluta do que nos constitui" (BERNABÉ; CHAMOISEAU; CONFIANT, 2015, p. 41). Dentre alguns dispositivos para o desenvolvimento da crioulidade, destacavam-se "escutar nossa música e provar nossa comida. Buscar como vivemos o amor, o ódio, a morte, o espírito que temos da melancolia, nossa maneira na alegria ou na tristeza, na inquietação e na audácia. Buscar nossas verdades" (BERNABÉ; CHAMOISEAU; CONFIANT, 2015, p. 40). E esta arqueologia crioula repousa menos no indivíduo e em seu livre arbítrio do que na comunidade, na qual a família ocupa um lugar preponderante enquanto espaço primeiro de socialização e de contato com a cultura em suas mais diversas manifestações, artes de fazer e de dizer que caracterizam o povo antilhano.

\section{Escrever a velhice: avós em perspectiva}

Patrick Chamoiseau (2016) define os mais velhos como "mestres e vítimas da ausência" (2016, p. 18). Por um lado, eles "se alimentam da ausência" (2016, p. 15), "seu olhar permanece preso ao que falta, ao que eles perderam. Desde então, submergidas pelas rugas, iluminadas por sorrisos tornados infantis, suas pupilas refletem tanto vulnerabilidades ternas quanto inocências ávidas" (2016, p. 15). Por outro lado, "eles são também mordidos pela ausência" (2016, p. 15), pois "eles estão se tornando alguma coisa que os apaga (o buraco negro das perdas, das rupturas e das faltas) da qual eles tiram o surpreendente paradoxo, e o triunfo tênue, de sua jornada" (2016, p. 16). Logo, "os que vivem muito tempo se aproximam de um mistério..." (2016, p. 16). E neste mistério habitam instâncias distintas: a decadência física, a vulnerabilidade, a perda da autonomia, os esquecimentos e as possíveis doenças acenam com um universo de renúncias e de apagamento. Em contrapartida, a sabedoria, o conhecimento, a experiência e as capacidades de aconselhar e de prever desfechos apontam para o auge da maturidade $e$ do entendimento da vida em diferentes veredas e negaceios. $O$ que parece lhes faltar no ponto de vista do vigor, da força e da destreza física se vê suplantado, em parte, pela acuidade intelecto-emocional acumulada ao longo dos anos. E assim seguem a jornada, equilibrando força e fragilidade como facetas da velhice. "Eles conhecem as batidas das alegrias e das dores, o cenário de sua existência é um conjunto de triunfos e derrotas repertoriados em uma única linguagem, sem alfabeto. [...] Tudo lhe falta e tudo lhe é dado: eles são tanto o que lhes falta quanto o que lhes habita" (CHAMOISEAU, 2016, p. 17). 
Uma precisão se faz importante. As reflexões de Chamoiseau sobre a velhice se realizam na obra La matière de l'absence [A matéria da ausência], escrita após o falecimento de sua mãe, Ninotte, cuja partida foi definida como "ausência fundamental" (2016, p. 18). Nesta ótica, o falecimento da matriarca se torna um convite - ou uma urgência - do filho mais novo em estabelecer uma conversa romanesca com a irmã mais velha, apelidada de Baronne, no intuito de compreender a partida da mãe e buscar no aconchego familiar meios de vivenciar o luto. Além disto, esta morte leva o escritor a observar a materialidade de ausências do dia a dia antilhano, o que o leva a perfazer um caminho literário acerca da memória, dos contadores de história, do cemitério, dos fantasmas, do sobrenatural, do passado de resistências da colonização e da escravização e dos invisíveis quotidianos. Como salienta o verso do poeta espanhol Antonio Machado, acolhido por Chamoiseau como uma das epígrafes da obra, "tudo passa e tudo permanece" (2016, p. 9) e assim, diante da perda da mãe, o escritor não tarda em lhe dedicar uma obra na qual confessa que "quando esta origem desaparece, a amargura pode engolir uma vida, ou então o coração das solidões pode conseguir se impor: posicionar em si a fonte refundadora e os princípios determinantes" (2016, p. 91).

Independentemente do caminho adotado, quer seja a melancolia, quer seja a capacidade de criar pele nova, a perda da origem se constitui num divisor de águas para os herdeiros. Ao se levar em conta o adágio de que "a morte exalta sempre a densidade da vida. Ela revela sempre a vida" (CHAMOISEAU, 2016, p. 228), este estudo volta suas atenções para textos antilhanos nos quais a figura de avós ocupa o primeiro plano. Nosso intuito consiste em observar que os avós, pais e mães duas vezes como defende a sabedoria popular, povoam de maneira sensível e superlativa a tradição literária caribenha. Em um espaço marcado pelas dores de origens fraturadas e rupturas intransponíveis engendradas pelo crime do tráfico negreiro, a valorização dos entes mais velhos e seu vínculo com a barbárie inaugural assume fundamental relevância.

No texto $\mathrm{Du}$ fond des casseroles [Do fundo das panelas], a guadalupense Simone Schwarz-Bart (2009) retoma o discurso por ela proferido em 1986 na Festa das cozinheiras. Trata-se de uma celebração nacional que ocorre há pelo menos 90 anos no sábado mais próximo de 10 de agosto, dia da morte de São Lourenço, patrono das cozinheiras da Guadalupe. Na narrativa, a autora discorre sobre as representações do ato de comer no arquipélago e o faz a partir de descrições minuciosas acerca da rotina do avô, assim definido: "meu avô pertencia a uma época onde a arte de viver à antilhana ainda estava intacto no povo. Seu dia começava com o sol e se encerrava com ele" (2009, p. 75). Mais adiante, o texto revela: "Meu avô era um homem comum, e seu dia era como o de muitas pessoas boas da Guadalupe. Comer, para ele, era uma operação que não tinha nada de científico. Era um pequeno empréstimo que ele fazia à natureza; e do qual ele era perfeitamente consciente" (2009, p. 78).

Levando-se em conta que "os pratos guardam sempre o prestígio do passado, a poesia de nosso solo e a doçura de nossas mais distantes lembranças" (EBROİN, 1989, p. 
184) e que "a cozinha era antes de tudo uma cozinha da partilha. Consideramos que o ato de comer sozinho é uma punição" (SCHWARZ-BART, 2009, p. 80), a presença do avô como instrumento para se apresentar as artes crioulas no domínio da gastronomia revela muitas facetas desta sociedade. Assim, na esteira do pensamento de Albert Memmi (2007), podemos vislumbrar a culinária como "valor refúgio". De início, chama a atenção o vínculo com o passado e a alusão imediata entre o ato de comer e as cenas em família. Em seguida, a constatação de que comer sozinho era um castigo, o que nos leva a pensar na comunhão dos encontros e na presença - mesmo em ausência física - dos mais velhos nestes momentos centrais. Ao se lembrar do avô ao discursar sobre a cozinha, Schwarz-Bart se recusa a esquecê-lo e o presentifica 4 (FOUCAULT, 1992, p. 155), trazendo-o de volta para a mesa familiar. O título do texto evoca o fundo da panela, o que nos leva a imaginar a parte que não se vê, a alquimia que se integra ao preparo do alimento, mesmo escapando aos olhos. Tal expressão pode fazer referência igualmente ao passado, às mãos invisíveis que seguram nas mãos dos que mexem as panelas e as vigiam sobre o fogo. Podem fazer menção também àqueles que ensinaram a receita, que souberam se coadunar com a natureza e seus frutos e que compuseram os menus tornados posteriormente típicos. Neste sentido, não nos furtamos de lembrar de rituais religiosos de homenagem ao sobrenatural através de goles de bebidas lançadas ao solo antes de serem de fato consumidas.

Em uma das cenas mais bonitas do discurso, a escritora afirma:

Se você estivesse ávido por determinado prato, qualquer que fosse, simples ou sofisticado, se você manifestasse por este prato um desejo anormal, alguém sempre lembrava um de seus ancestrais que era tão ávido quanto você por este prato e, então, se dizia: 'Naturalmente, fulano era teu avô, é muito natural que ele tenha os mesmos gostos que ele'. (SCHWARZ-BART, 2009, p. 79).

Assim, reiteram-se as leituras já propostas sobre ancestralidade-árvore, sobre húmus que se recicla para observar os resíduos que nos compõem, o mosaico que nos forja. Neste trecho, a autora lança luz sobre o fato de nossos gostos retomarem gostos de nossos ancestrais. É conhecida a sentença popular de que alguém "puxou" características físicas, emocionais e comportamentais de seus progenitores. Contudo, na narrativa de Simone, este elo com o passado parece mais forte, imprimindo-se nos herdeiros de modo profundo e indelével. Deste modo, no texto, a narradora se assume como neta cujos fios se conectam ao avô, prolongando sua presença e ventilando seus ensinamentos. A simbiose entre neta, avô e tradições culinárias em Guadalupe se avoluma de tal forma que ao longo da leitura já não é possível saber se o tema da gastronomia evoca o avô ou o desejo de falar do avô conduz a escritora ao tema. Confundem-se todos os limiares sob o paradigma dos afetos e

\footnotetext{
4 O termo elaborado por Foucault (1992) depreende de seus estudos sobre a epistolografia. Para o crítico francês, o ato da redação de cartas presentifica o destinatário e o ato da leitura da missiva pelo destinatário presentifica o remetente. Propomos um alargamento do conceito foucaultiano ao compreendermos que o conceito de presentificação não se limita ao âmbito das correspondências. Ele pode ser percebido em demais situações nas quais a fala burla a ausência com um discurso que presentifica aquele que não desejamos ausente.
} 
das lembranças.

Por fim, cabe ressaltar que temos notícia de pelo menos duas publicações do discurso proferido por Simone Schwarz-Bart, sendo a primeira na revista Autrement, cujo número 41, de 1989, foi dedicado às Antilhas e, a segunda, na coletânea Nouvelles de Guadeloupe [Novelas da Guadalupe], de 2009. Esta última publicação pretende apresentar a literatura guadalupense através de novelas de seus mais conhecidos escritores, mecanismo de promoção literária vislumbrado pelas editoras Magellan \& Cie e Desnel com dezenas de outras nações em diferentes continentes. Sob esta perspectiva, chama a atenção o fato de um texto de uma neta sobre o avô - ou sobre a gastronomia através do comportamento alimentar do avô - ser reconhecido como capital para a compreensão dos rumos, das dicções e das vozes desta literatura.

O binômio gastronomia e avó compõe a intriga do romance Victoire, les saveurs et les mots [Vitória, os sabores e as palavras], de 2008, de Maryse Condé. Na contramão da empreitada schwarzbartiana de se rememorar do avô, retendo-o nas malhas do discurso a partir das lembranças que ele legou, a narradora desta obra escreve para buscar conhecer a avó falecida antes de seu nascimento. De flagrante cunho autobiográfico e dedicado por Condé às três filhas e duas netas, o romance busca reabilitar Victoire Élodie Quidal, empregada doméstica e cozinheira renegada por Jeanne Quidal, mãe de Maryse Condé. Jeanne foi definida pela filha como uma mulher orgulhosa, "insatisfeita e frustrada" (CONDÉ, 2015a, p. 80), "alienada" (2015a, p. 16), "incapaz de pedir perdão" (2015a, p. 83) que não queria admitir ser "filha de uma bastarda analfabeta" (2015a, p. 79) e mais do que isto, filha de um estupro. Por isto, menosprezou o quanto pôde a herança materna e não falava da progenitora.

Inscrito sob o arquétipo de "reconstituição" (CONDÉ, 2013, p. 9) e imbuído da premissa de que "inventava universos na minha fantasia" (2015a, p. 70), o livro configura uma busca incansável pela avó:

Agora tenho o gosto de seguir seus passos. Sua imagem é desconfortável, difícil de cernir. Para uns, ela foi bonita. Para outros, pálida e feia. Para alguns, foi uma criatura submissa, iletrada, sem interesse. Para outros, um verdadeiro Maquiavel de saias. Para falar dela, minha mãe utilizava clichês muito usados nas Antilhas [...]: - Ela não sabia nem ler nem escrever. Entretanto, era um poto-mitan ${ }^{5}$, uma toureira. (CONDÉ, 2013, p. 18)

"Eu entrego o retrato que consegui traçar do qual certamente não garanto a imparcialidade, nem mesmo a exatidão" (CONDÉ, 2013, p. 19). Nestes termos, Condé redige a biografia romanceada da avó na tentativa de preencher a insuportável lacuna de sua ausência, de amenizar a dor dos silêncios familiares e de uma existência negada, obliterada. Assim, cria uma avó-personagem, uma avó de papel para lhe fazer companhia e com ela compartilhar os prazeres e os segredos da cozinha. Na obra desfilam episódios como a primeira comunhão, a descoberta da cozinha, o trabalho como doméstica, o apreço

\footnotetext{
${ }^{5}$ Mais adiante, nos ateremos a este conceito.
} 
pela música, a morte prematura da mãe, a penúria financeira, os pés sempre descalços e os embates com a madrasta.

Ao longo da empreitada literária, a narradora confessa: "ninguém saberá das relações de Victoire, minha avó [...] Riscada esta história. Eliminada das memórias. Mas, eu quero saber" (2013, p. 66). Decidida a estabelecer contato póstumo com a matriarca, tirá-la do anonimato, transformá-la em heroína, enumera as dificuldades da tarefa: "não temos nenhuma prova. [...] Somente um feixe de indícios nos guiam" (2013, p. 105), para, em seguida bradar: "Posso somente imaginar" (2013, p. 67), "Sonhemos" (2013, p. 117). Durante a intriga, toma partido da avó, se torna sua cúmplice e aliada, vociferando contra os que não a ouviram e não a compreenderam "O que me revolta, é que neste episódio ninguém nunca considerava Victoire como uma vítima” (2013, p. 74).

Desta forma, Maryse Condé transforma a tessitura literária em documento de batismo, retrato, mortalha. Em sua ode-conversa, busca suplantar o desprezo, a indigência, a morte e o esquecimento que acompanharam a trajetória da mulher simples, sofrida e exímia cozinheira. Propõe uma parceria, estende a mão para a avó, dizendo-lhe que ela não está sozinha. Na contramão da atitude materna que insiste em sepultar a mãe e envolver sua trajetória num silêncio sepulcral e indiferente, a neta brada aos quatro ventos o que a avó poderia ter sido, costura informações colhidas aqui e acolá com muitas pitadas de imaginação para compor uma obra robusta na qual o nome da avó figura desde o título. E no título, a avó se vê ladeada por sabores e palavras, instâncias que sobrepuseram o tempo, a distância e os silenciamentos para aproximarem sobremaneira a genealogia feminina das Quintal.

É fundamental mencionar o fato de Maryse Condé ser uma grande cozinheira, faceta vislumbrada no livro Mets et merveilles [Pratos e maravilhas] (2015b), no qual ela declara: "ser uma excelente cozinheira contribuía também para mim para quebrar essa imagem de intelectual, de militante e de feminista que facilmente atribuem a mim" (2015b, p. 12). Logo, por meio de caminhos tortos, imprevisíveis e mágicos, a neta herda os dotes culinários da avó desconhecida, rasurando uma mãe "incapaz de cozinhar um ovo" (2013, p. 15). A despeito dos esforços da mãe, tudo leva a crer que havia uma força maior a unir avó e neta: "o que eu quero é reivindicar a herança desta mulher que aparentemente não deixou nenhuma" (2013, p. 104).

No ensaio Écrire en pays dominé [Escrever em país dominado], de 1997, Patrick Chamoiseau discorre sobre a escrita em tempos de dominação silenciosa na Martinica. Para compreender as reflexões do autor, atentemos para o fato de que tanto a Martinica quanto a Guadalupe se tornaram Departamentos ultramarinos franceses em 1946, em ato jurídico que encerrou a colonização nas ilhas caribenhas e as assimilou ao formato político departamental da França metropolitana. Dito isto, observa-se que as ilhas não configuram países, em stricto sensu, tampouco são espaços que desfrutam de soberania nacional. Esta complexa configuração de assimilação ao antigo colonizador leva Chamoiseau a dedicar seu ensaio sobre uma dominação ainda flagrante na relação entre as ilhas e a ex- 
metrópole, dominação esta caracterizada por ele como silenciosa.

No ensaio, Chamoiseau inaugura o procedimento dos diálogos com os mais velhos retomado no romance sobre a matéria da ausência, na qual convoca a irmã mais velha. $\mathrm{Na}$ obra de 1997, a conversa se estabelece com um alterego intitulado vieux guerrier (velho guerreiro) cuja frase - deixa "o velho guerreiro me deixa ouvir" (CHAMOISEAU, 2011, p. 29) anuncia a fala do mestre, escrita com letras em itálico, distanciamento da margem e fonte menor do que a do restante do texto. O procedimento aponta para um dos recursos mais significativos da citação: acolher a voz do outro, fazer com ela "contato, fricção, corpo a corpo" (COMPAGNON, 2007, p. 36). Emoldurá-la de espaços em branco, atribuir-lhe prestígio, notoriedade. Uma voz que ecoa em outro texto, povoando-o, questionando-o, complementando-o. Neste sentido, a citação promove uma "sobrevivência" (COMPAGNON, 2007, p. 12) da voz que se aninha no novo espaço. Em Chamoiseau, esta voz é aquela da experiência, daquele velho contador de histórias que parece tudo conhecer e que fala com propriedade de temas variados. Encarnação da sabedoria, o velho guerreiro assume o papel de um avô disposto a formular precisões, dar exemplos e explicar em detalhes os temas desenvolvidos pelo pupilo mais jovem. Explicada à miúde nas páginas finais da obra, a presença deste interlocutor ganha novos vultos, como o de "companheiro de palavra" (CHAMOISEAU, 2011, p. 349):

O velho guerreiro murmurou no meu ouvido uma espiral sem fim. [...] Ele era a Voz sem corpo de velhas mitologias, alma das pedras, vela cantora das fontes, respiração dos contos, sobressalto de minhas carnes mortas transformadas em matéria, ao mesmo tempo grito vocalização canto e linguagem e além disto respirações informuláveis das mais antigas memórias. Balbuciador. Percebedor de evidências. Polidor de palavras inúteis. Eu lhe murmurei as minhas, estes sonhos fugidios. Nós nos repetíamos a ritmos diferentes. Buscando-nos nas mesmas dores, mas não ao mesmo tempo. Eu no meu Lugar-em-devir, ele no Mundo. (CHAMOISEAU, 2011, p. 348-349).

Neste momento, compreendemos a velho guerreiro para além de sua vocação para dissertar e lecionar. Na obra, ele assume a função de burilador da voz do "neto", desempenhando o papel de primeiro incentivador, primeira plateia, voz inaugural na qual se imprimem um palimpsesto de vozes antilhanas. Esta Voz, grafada em letra maiúscula pelo autor, torna-se gênese das demais vozes, torna possível outros discursos. Assim, este desbravador ganha contornos hiperbólicos, aproxima-se da figura do gênio, mitologia originária. Ele transborda um corpo, uma vida e assume feições do passado e do presente em diálogo.

E, neste ponto, o livro de Chamoiseau (2011) se imbrica profundamente à história das ilhas, reconhecendo ser o velho o único detentor possível da palavra e alçando-o ao panteão do discurso. É preciso percebermos que a voz masculina, no contexto da escravização, viu-se usurpada pelo mestre colonizador. O escravizado, no âmbito da sociedade colonial, tornou-se destituído de muitos papeis comumente atribuídos aos homens, tais como a manifestação da virilidade, a constituição e manutenção da família, o 
sustento da casa, a proteção das mulheres. Assim, fragilizado, castrado de sua inteireza e limitado em seu papel social, os homens foram emudecidos. Acerca deste cenário de subalternizações, a pesquisadora Vanessa Borilot (2014) nos ensina que

a palavra do pai afro-caribenho pode emergir (apenas) em um espaço simbólico e um status simbólico quando ele é quilombola, velho ou participa do imaginário crioulo (o dorlis e o l'homme au bâton ${ }^{6}$ ). Neste nível, o confronto com o Béké ${ }^{7}$ é indireto, pois ou os dois não compartilham o mesmo espaço, ou o velho não representa ou não representa mais um perigo para seu proprietário. (2014, p. 121, grifos nossos).

Na análise de Borilot, (2014) chama à atenção a forma como a fragilidade física dos velhos se tornou um escudo para insurreições silenciosas por eles capitaneadas. Aos olhos dos donos do poder, eram apenas figuras em compasso de espera para a morte e não ofereciam perigo algum à manutenção do sistema. Protegidos pela cegueira institucional, pelo desprezo que desencadeavam - e aqui passamos em revista a lição de Manoel de Barros para não se "desprezar as coisas desprezíveis /E nem os seres desprezados" (2018, p. 18) -, tornaram-se a voz masculina da resistência, da re-existência. Tornaram-se baluartes sob a égide de que eram "velhos demais para morrer" (MARIANO, 2020), sábios demais para capitular, perspicazes demais para calar.

Na obra La matière de l'absence, Patrick Chamoiseau retoma a figura do guerreiro, sob o seguinte plano: "pelo único fato de estar vivo em uma pele negra, você se tornaria escravo, quero dizer: morto mesmo permanecendo catastroficamente vivo... O único meio de sair disto: mudar o imaginário!... Tornar-se um Guerreiro do imaginário..." (2016, p. 31). E desta vez, o guerreiro passa a merecer a grafia em letra maiúscula. Desta forma, o autor martinicano nos lega um postulado norteador para a compreensão da velhice no cenário antilhano: escrever em país dominado, afrontar dominações silenciosas e optar pela insurgência em suas múltiplas formas constituem atividades para serem enfrentadas ao lado dos velhos, tendo-os como esteios, pilares, braços que empurram para frente, pés que demonstram caminhos, vozes que ecoam lutas de ontem e de hoje, interlocutores que promovem a escrita.

Em um contexto onde as vozes masculinas se veem obliteradas e precisam lutar contra a dominação, as vozes femininas acabaram por assumir o primeiro plano no imaginário antilhano. Para elas, foi cunhado um conceito amplamente difundido: "poteau-

\footnotetext{
${ }^{6}$ Trata-se de duas figuras do folclore crioulo, também conhecido como universo mágico-religioso: o dorlis é um espírito quem tem a capacidade de se transformar, de entrar à noite no quarto feminino e abusar delas durante o sono, sem que percebam ou despertem. No universo brasileiro, L'homme au bâton (homem com vara em tradução ipsis litteris) pode ser aproximado à figura folclórica do boto: homem charmoso, encantador e sedutor que leva as mulheres para o rio, as engravida e desaparece.

7 O Béké é o colono branco nas Antilhas. Foi o detentor do poder colonial durante a empreita colonialista e, mesmo após a abolição escravista e a departamentalização de 1946, continua a exercer (e a controlar) os poderes político, econômico e sociais nas ilhas.

${ }^{8}$ Título do romance de Vinícius Neves Mariano, laureado com melhor romance no Prêmio Malê de Literatura 2019 e publicado em 2020. O autor constrói uma narrativa em torno do envelhecimento da população e questiona o sentido de envelhecer num mundo que se acostumou a desprezar a velhice.
} 
mitan", também grafado como "poto-mitan" ou "potomitan". A escritora martinicana Gaël Octavia explica o termo:

O poteau-mitan, ou seja, a mulher como pilar da casa, é [um termo] supervalorizado e reverenciado ali. A Martinica é uma sociedade patriarcal, mas matrifocal, no sentido de que muitas mulheres criam seus filhos sozinhas. Às vezes, são filhos de pais diferentes, muitas vezes ausentes. [...] O poteau-mitan é isso: uma mulher que assume tudo; o pai dos filhos pode ir embora, ela vai se virar sozinha, vai lutar, criar os filhos. E amá-los. (OCTAVIA apud AIDARA, 2017).

Em entrevista, Patrick Chamoiseau delineia explicações histórias para o termo e tece críticas para os perigos que ele fomenta na sociedade:

o que se chama de família matrifocal, voltada para a mãe. E então ... esta talvez seja também a lenda que diz que a mulher é o poteau-mitan ... É certo que quando nos deparamos com uma situação de desumanização tão profunda quanto aquela da escravidão, eu acho que quem tem uma criança quer que, pelo menos ela, escape disso. Acho que isso deve ter determinado na psique feminina das Antilhas, em todo caso maternal, uma atitude de sacrifício. A mãe é totalmente devotada aos filhos e toda a energia das mulheres nas plantações é para empurrar os filhos para escapar dessa condição. Isso poderia ter determinado esse tipo de posição de martírio frequente nas mulheres antilhanas - que faz de tudo ... que se sacrifica pelos filhos. (CHAMOISEAU apud CHINIEN, 2008).

Outros intelectuais se debruçaram sobre o tema. Daniel Maximin reconhece o fato da mulher ser "o pilar de organização social" (2006, p. 46) e Raphaël Confiant associa o poteau-mitan ao "orgulho e à ajuda de todos os seus" (2012, p. 167). A pesquisadora belga Kathleen Gyssels (2008) descortina a origem religiosa do tema, explicando que

o poteau-mitan em vodu é o peristilo em torno do qual dançam os iniciados ou "hounsis" (seguidores). Os iniciados colocam oferendas ali, enquanto "vévés" são traçados na terra batida ao redor desta pilastra de madeira que indica o eixo vertical que indica a comunhão com os espíritos, com os mortos e os deuses. (2008, n. p, grifos da autora).

Se atentarmos para cada componente do termo, temos "poteau", como poste, pilar, pilastra, coluna e "mitan" como meio, metade. Trata-se do poste de sustentação das casas sobre os quais repousam o teto e o telhado; esteio arquitetural em torno do qual manifestações do vodu se realizam. De fato, a linhagem maternal é aquela que "afronta a adversidade" (MONAN, 2001, p. 133) e não podemos perder de vista a anedota segundo a qual "para designar uma coisa impiedosa a língua crioula diz que ela é 'sem mãe"” (CHAMOISEAU, 2016, p. 91).

Simone Schwarz-Bart (1986) apresenta a personagem Télumée, narradora e protagonista de $A$ Ilha da chuva e do vento, a partir da canção "Menina cana-roxa, senhoras / uma cana-roxa ao vento / Ela pende e se ergue / Ela se ergue e pende / É preciso vê-la dobrada, senhoras" (1986, p. 132). Eis a imagem de uma mulher que enverga, toca o solo 
diante das intempéries da vida. Após as adversidades, contudo, ela retoma a posição ereta e sobrevive aos sobressaltos. A imagem da maleabilidade e da força feminina evocadas por Schwarz-Bart povoam o imaginário literário antilhano. Estabelecendo um diálogo com a autora, o conterrâneo Daniel Maximin (2006) retoma a fábula de La Fontaine acerca do carvalho e do caniço como chaves de leitura para a resistência antilhana. O caniço, apesar da aparente fragilidade, curva-se diante das tempestades e reergue-se, ao passo que o carvalho, mais forte e rijo, é destruído. Por sua vez, Maryse Condé, matriarca do arquipélago, parte do provérbio "a mulher é uma castanha, o homem é uma fruta-pão" (1993, p. 4) para ilustrar a "capacidade de resistência da mulher" (1993, p. 4) e "sua faculdade de se sair melhor do que o homem de situações que abatem" (1993, p. 4). Apesar das semelhanças de folhagem e de formato de frutos entre as duas árvores, a castanha, quando emadurece e cai no chão, dá frutos, enquanto a fruta-pão se desfaz, produzindo uma pasta que se esparrama no solo e exala mal odor.

Este breve panorama a propósito da força feminina na sociedade caribenha nos permite assimilar a quantidade superlativa de obras em homenagem às mães e avós na paisagem literária caribenha. Simone Schwarz-Bart compôs provavelmente uma das mais conhecidas: Pluie et vent sur Télumée Miracle, de 1972, que foi traduzida por Estela dos Santos Abreu para o português em 1986 com o título de A ilha da chuva e do vento, romance ao qual já fizemos menção para exemplificar as sagas familiares e a resistência feminina. Traduzida em dezenas de idiomas e laureada com Grande prêmio dos leitores da revista Elle, em 1973, a obra, como já mencionamos, passa em revista quatro gerações da família Lougandor: Minerve, Toussine, Victoire e Télumée. Esta última é a narradora do livro, que se organiza em duas partes de tamanho e fôlego desiguais: "apresentação dos meus" e "história da minha vida".

Victoire relega a educação da filha mais velha à avó Toussine e parte viver sua história de amor levando consigo apenas a filha mais nova: "decidiu mandar-me para Fond-Zombi, para a casa de minha avó, bem longe de seu caraíba" (SCHWARZ-BART, 1986, p. 42). Dilacerada pelo abandono materno, tema incomum na realidade antilhana, Télumée suplanta o desarrimo familiar pela acolhida sensível da avó:

A cabana de Rainha-Sem-Nome era a última do lugarejo, era o término do mundo humano e parecia recostada na montanha. Rainha-Sem-Nome abriu a porta e me fez entrar no pequeno cômodo que era toda a sua casa. Assim que transpus a soleira, senti-me como numa fortaleza, ao abrigo de todas as coisas conhecidas e desconhecidas, sob a proteção da grande saia franzida de minha avó. (SCHWARZ-BART, 1986, p. 43)

Esta mudança de lar e de ares será significativa para a menina, que descobre no colo da avó o real significado de família, de afeição e de proteção. Sob a tutela da avó, a menina se torna uma mulher forte e consciente de suas feridas. O episódio se torna um divisor de água para ambas, encontro de solidões, abandonos, fragilidades que se fortalecem juntas, alterando o rumo da existência. A se ressaltar que à época em que adota a neta em sua cabana, Toussine já era viúva e vivia sozinha, num bairro pobre afastado de tudo e de 
todos. A presença da neta sopra vida para dentro de uma avó cansada que já não fazia planos nem esperava graças.

Télumée propõe uma definição para a velhice, a partir da metáfora da água e de seu fluxo:

minha avó não tinha mais idade para agachar-se na terra dos brancos, amarrar os feixes de cana, arrancar o mato, mondar, cortar o vento, macerar o corpo ao sol como sempre havia feito. A hora da velhice havia fechado, o curso de sua vida baixara; era agora uma água pouca que escorria lentamente entre as pedras, num parco movimento cotidiano, alguns gestos para alguns tostões. (SCHWARZ-BART, 1986, p. 45).

Se o jovem se aproxima da imagem de um rio cujas águas abundantes jorram, a velhice assume os contornos de uma água diminuta que flui lentamente. Ao se pensar na água como metáfora da vida, a velhice se sagra como reta final deste percurso. "Eu sempre gostava de ouvir os elogios dela" (1986, p. 48), confessa a neta sobre a sintonia e os afagos da avó. Episódios vários de chamegos entre as duas gerações das Lougandor pululam na obra: "minha vó sentava-se na cadeira de balanço, na entrada da cabana, puxava-me para as suas saias e, com um suspiro de satisfação a cada movimento dos dedos, começava a fazer devagar as minhas tranças. Nas suas mãos, o pente de metal só arranhava o vento" (1986, p. 47).

Para a avó, a neta personifica a "árvore da felicidade" (1986, p. 54) e aqui se reiteram nossos apontamentos sobre árvore-húmus-genealogia. O encontro das duas, a força deste contato e a explosão de afetividade serão rememorados e exaltados na narrativa:

"Ela, a minha velha, só esperava por mim para derramar as últimas ondas de sua ternura, reacender o brilho dos olhos gastos. Estávamos naquele ermo, apoiada uma à outra [...] Ela vivia por mim, respirava por minha boca. Se eu saía, ela entrava numa agitação que só acabava quando eu chegava. (1986, p. 62).

Contadora de histórias, Toussine era detentora de uma sabedoria ímpar e de boa dose de otimismo. Em "tom de oráculo" (1986, p. 141), ofertava com grande generosidade lições e ensinamentos para os mais jovens, como neste trecho em que discorre sobre a importância de resistir e seguir em frente: "depois de todos os percalços, ciladas e surpresas, simplesmente recobrar o fôlego e continuar na mesma marcha" (1986, p. 61).

Quando Télumée se casou e passou a ser agredida pelo marido, os laços entre a neta e a avó ganharam novos contornos e Toussine redobra as forças para cuidar das feridas físicas e psicológicas da herdeira, tornando-se uma guardiã como poucas vezes se viu: "graças a ela, eu comia, bebia, e até as compras da minha casa era ela quem fazia" (1986, p. 146). Neste momento, a fragilidade física da matriarca se torna secundária e o que se vê é uma senhora sempre em alerta disposta a salvar a neta: "Assim, no final de sua vida, minha avó fabricava vento para enfunar minhas velas, para me ajudar a retomar a viagem sobre as águas" (1986, p. 160). 
Tudo leva a crer que a redenção da neta, que se separa do marido agressor, passa a morar sozinha e assume as rédeas da vida, torna-se uma permissão para que a avó volte suas atenções para si, dê conta de sua idade avançada e sua doença, o que desembocará em sua queda e em sua morte. De fato, "sem o farol de minha [sua] avó" (1986, p. 168) como presença carnal, Télumée se aproxima dos mistérios religiosos, torna-se contadora de histórias e curandeira, começando a contar com outro tipo de proteção da matriarca: "já imaginaste a nossa vida, eu te seguindo sempre, invisível, sem que ninguém desconfie que está tratando com duas mulheres em vez de uma só?..." (1986, p. 165). Como se vê, a simbiose neta-avó transporá todos os limites e ressignificará a compreensão de vida e de morte.

A maior das homenagens da neta para a avó será a escrita do romance a partir do paradigma "entendi então que a proteção dos mortos não substitui a voz dos vivos" (1986, p. 183). Pela voz de Télumée, a transmissão das peripécias de Toussine e de todo seu legado serão assegurados. Assim, a menina que amadurece pedindo a avó "fala-me da vida, minha avó, fala-me dela" (1986, p. 158), assume o papel de falar da vida da matriarca, exemplo maior de retidão de caráter, de resiliência diante de todos os obstáculos. Télumée não foi mãe, não legou aos herdeiros consanguíneos a tradição das Lougandor, na qual a personagem da avó emerge como aquela que reinventa os rumos da velhice diante das necessidades da neta, aquela que transforma as necessidades e percalços desta em razões a mais para enfrentar cada dia. De fato, desde a página de abertura, a obra assume o tom de elogio à avó:

Quando eu era pequena, minha mãe Victoire sempre me falava de minha avó, a negra Toussine. Falava com fervor e veneração, [...] afirmava que Toussine era a mulher que ajudava qualquer um a não baixar a cabeça diante da vida, e raros possuem esse dom. Minha mãe a venerava tanto que acabei por considerar a avó Toussine um ser mítico, morando para lá no mundo e, embora ainda viva, era para mim uma espécie de lenda. (1986, p. 9).

Assim, o altruísmo de Toussine perpassa toda a obra. Victoire, a filha que abdica de Télumée, era sua filha mais nova, aquela que nasceu depois da morte trágica de Méranie. E justamente esta filha arco-íris, como define a sabedoria popular, filha tão amada, vira as costas para a mãe, viaja sem nem olhar para trás e cede a educação de Télumée para a avó. E neste momento de decepção com a filha que rompe com o valor refúgio familiar, Toussine aprende a grandeza de ser avó e de cuidar da formação de alguém tão vulnerável e tão assustado com tudo que a cercava. Transforma, deste modo, a frustração com a partida da filha na alegria de ter uma neta para chamar de sua. Em outras palavras, a partir das dores da maternidade ferida, surge a avó na inteireza dos que se sabem incompletos.

"Eu me acostumei a chamar a minha avó pelo nome que as pessoas lhe deram, Rainha-sem-nome; mas o seu nome, de fato, era Toussine Lougandor" (1986, p. 9). Por fim, é imperativo explicar como Toussine se torna a Rainha. Esta transformação remete ao renascimento provocado pela gestação de Télumée após a morte de Méranie, gestação 
que arrancará a mãe de uma depressão severa e uma vida desgovernada e lhe permitirá se tornar protagonista de seu destino, ilustração da força inabalável de uma "poteau-mitan":

Lembrava-se da Toussine de outrora, esfarrapada, e comparavam-na com a de hoje, que não era uma mulher, pois, o que é uma mulher?.... um nada, diziam, ao passo que Toussine era um pedaço de mundo, todo um país, um fulgor de negra, o barco, a vela, por não ter sucumbido à infelicidade [...] Procuramos um nome de rainha que te conviesse mas não achamos. De fato, não há nome para ti. Assim, doravante, nós te chamaremos de RainhaSem-Nome. E os negros beberam, comera, festejaram. Desde esse dia chamam minha vó de Rainha-Sem-Nome. (1986, p. 25-26).

Por certo, o misto de sacrifício e afeto matricial observados em Toussine ultrapassam a personagem e fazem dela um símbolo da condição de "avó". Não há nome capaz de explicar um reinado marcado pelo luto de duas filhas (a falecida e a desertora) e pelo zelo com a neta abandonada. E neste ponto, parece que os personagens Rainha-Sem-Nome e o Velho guerreiro se dão as mãos: figuras que encarnam a magia de ser avó e avô como uma missão capaz de suplantar individualidades. E mais do que isto, cujo maior objetivo é continuar a tecer fios invisíveis e misteriosos que vêm do passado. Dois personagens contadores de histórias transformados em seres de papel por netos escribas cientes dos procedimentos literários em driblar e burlar a morte e a ausência. Netos dispostos a colher memórias de velhos (BOSI, 1979, p. 3).

\section{Referências}

AIDARA, Aminata. Gaël Octavia: «Je voulais raconter l'histoire d'une anti poto-mitan». Africultures, 24 nov. 2017. Disponível em: http://africultures.com/gael-octavia-voulaisraconter-Ihistoire-dune-anti-poto-mitan. Acesso em: 16 out. 2020.

BARBOSA, João Alexandre. Uma psicologia do oprimido. In: BOSI, Ecléa. Memória e Sociedade: lembranças de velhos. São Paulo: T. A. QUEIROZ EDITOR, 1979, p. XI-XV.

BARROS, Manoel de. Memórias inventadas. Rio de Janeiro: Alfaguara, 2018.

BERNABÉ, Jean; CHAMOISEAU, Patrick; CONFIANT, Raphaël. Éloge de la créolité. Paris: Gallimard, 2015.

BERND, Zilá; SOARES, Tânia. Modos de transmissão intergeracional em romances da literatura brasileira atual. Alea: Estudos neolatinos, Rio de Janeiro, v. 18 n. 3, p. 405-421, 2016. Disponível em: http://www.scielo.br/scielo.php?pid=S1517106X2016000300405\&script=sci_abstract \&tIng=pt. Acesso em: 7 out. 2020.

BORILOT, Vanessa Christine. En mal de mots: représentations de la figure paternelle Dans les littératures de la Caraïbe et des Mascareignes. 2014. Tese (Doutorado em Filosofia) Department of Philosophy, University of lowa, lowa City. Disponível em: https://doi.org/10.17077/etd.sguuymp2. Acesso em: 4 jun. 2020.

BOSI, Ecléa. Memória e Sociedade: lembranças de velhos. São Paulo: T. A. QUEIROZ EDITOR, 1979. 
BOSI, Ecléa. O tempo vivo da memória: ensaios de psicologia social. São Paulo: Ateliê Editorial, 2003.

CÉSAIRE, Aimé. Discurso sobre o colonialismo. Trad. de Anísio Garcez Homem. $1^{\text {a }}$ reimp.. Florianópolis: Letras contemporâneas, 2017.

CHAUÍ, Marilena. Os trabalhos da memória. In: BOSI, Ecléa. Memória e Sociedade: lembranças de velhos. São Paulo: T. A. QUEIROZ EDITOR, 1979, p. XVII-XXXII.

CHAMOISEAU, Patrick. Que faire de la parole? In: LUDWIG, Ralph. Écrire la parole de nuit - la nouvelle littérature antillaise. Paris: Gallimard, 2002, p. 151-158.

CHAMOISEAU, Patrick. Écrire en pays dominé. Paris: Gallimard, 2011.

CHAMOISEAU, Patrick. La matière de l'absence. Paris: Seuil, 2016.

CHINIEN, Savrina Parevadee. «Je fais un travail d'exploration existentielle» Entretien de Savrina Parevadee Chinien avec Patrick Chamoiseau. Africultures, 30 jan. 2008. http://africultures.com/je-fais-un-travail-dexploration-existentielle-7279/. Acesso em: 5 ago. 2020.

COMPAGNON, Antoine. O trabalho da citação. Trad. de Cleonice P. B. Mourão. Belo Horizonte: UFMG, 2007.

CONDÉ, Maryse. La parole des femmes. Paris: L'Harmattan, 1993.

CONDÉ, Maryse. Victoire, les saveurs et les mots. Paris: Mercure de Framce, 2013.

CONDÉ, Maryse. Le cœur à rire et à pleurer - contes vrais de mon enfance. Paris: Robert Laffont, 2015a.

CONDÉ, Maryse. Mets et merveilles. Paris: LC Lattès, 2015b.

CONFIANT, Raphaël. Dictionnaire des titim et sirandanes. Martinique: Ibis Rouge, 1998

CONFIANT, Raphaël. La Jarre d'or. Paris: Mercure de France, 2012.

DAMATO, Diva. Édouard Glissant - poética e política. São Paulo: ANNABLUME/FFLCH, 1995.

DODMAN, Maria João. Representações da velhice e do envelhecimento na obra de Dias de Melo. Veredas, n. 24, p. 120-133, 2015.

EBROÏN, Ary. Les origines de la cuisine créole. Revue Autrement, n. 41, p. 178-184, 1989.

FOUCAULT, Michel. A escrita de si. In: FOUCAULT, Michel. Ética, sexualidade e política. Rio de Janeiro: Forense Universitária, 1992, p. 129-160.

GLISSANT, Édouard. Le discours antillais. Paris: Gallimard, 2012.

GYSSELLS, Kathleen. Le «poteau-mitan», du péristyle vaudou à la famille matrifocale. Potomitan, 2008. Disponível em: https://www.potomitan.info/penteng/potomitan.php. Acesso em: 20 out. 2020. 
HERBECK, Jason. Entretien avec Fabienne Kanor. The French Review, v. 86, n. 5, apr. 2013.

http://scholarworks.boisestate.edu/cgi/viewcontent.cgi?article=1045\&context=lang_facpub s. Acesso em: 23 jul. 2020.

HUSTON, Nancy. A espécie fabuladora. Trad. de Ilana Heineberg. Porto Alegre: L\&PM, 2010.

JEANNE-ROSE, Marcelle. Seniors en Martinique: un enjeu économique. Revue Insee Analyses Martiniques, n. 10, 2016.2 Disponível em: https://www.insee.fr/fr/statistiques/2128984. Acesso em: 15 out. 2020.

JUMINER, Bertène. La parole de nuit. In: LUDWIG, Ralph. Écrire la parole de nuit - la nouvelle littérature antillaise. Paris: Gallimard, 2002, p. 131-150.

KANOR, Fabienne. D'eaux douces. Paris: Gallimard, 2004.

KANOR, Fabienne. Humus. Paris: Gallimard, 2006.

LANCASTRE, Dominique. La véranda. Paris: Éditions FORTUNA, 2014.

MARIANO, Vinicius Neves. Velhos demais para morrer. Rio de Janeiro: Malê, 2020.

MAXIMIN, Daniel. Les fruits du cyclone - Une géopoétique de la Caraïbe. Paris: Seuil, 2006.

MEMMI, Albert. Retrato do colonizado precedido pelo retrato do colonizador. Trad. de Marcelo Jacques de Moraes. Rio de Janeiro: Civilização Brasileira, 2007.

MONAN, Alexandre. Joanise ma mère. Fort-de-France: Éditions Emile Désormeaux, 2001.

SCHWARZ-BART, Simone. A ilha da chuva e do vento. Trad. de Estela dos Santos Abreu. São Paulo: Marco Zero, 1986.

SCHWARZ-BART, Simone. Du fond des casseroles. Nouvelles de la Guadeloupe. Paris: MAGELLAM \& CIE/Éditions Desnel, 2009, p. 74-81.

TAUBIRA, Christiane. L'esclavage raconté à ma fille. Paris: Éditions Philippe Rey, 2015.

WABERI, Abdourahman A. Uma carta para a juventude. Unesco, 2018. Disponível em: https://pt.unesco.org/courier/2018-2/uma-carta-juventude. Acesso em: 13 out. 2020.

\section{NOTAS DE AUTORIA}

Vanessa Massoni da Rocha (vanessamassonirocha@gmail.com) é professora de Língua francesa e de Literaturas francófonas no Instituto de Letras da Universidade Federal Fluminense. Vice-líder do grupo de pesquisa Identidades em trânsito: estéticas transnacionais, cadastrado no CNPq. Suas pesquisas acadêmicas se inscrevem no âmbito da francofonia, mais precisamente no estudo de obras de expressão francesa do Caribe.

\section{Como citar esse artigo de acordo com as normas da ABNT}

ROCHA, Vanessa Massoni da. Colher memórias de velhos: retratos de avós em obras do Caribe francófono. Anuário de Literatura, Florianópolis, v. 26, p. 01-22, 2021.

\section{Contribuição de autoria}

Não se aplica. 


\section{Financiamento}

Não se aplica

\section{Consentimento de uso de imagem}

Não se aplica.

\section{Aprovação de comitê de ética em pesquisa}

Não se aplica.

\section{Conflito de interesses}

Não se aplica.

\section{Licença de uso}

Os/as autores/as cedem à Revista Anuário de Literatura os direitos exclusivos de primeira publicação, com o trabalho simultaneamente licenciado sob a Licença Creative Commons Attribution (CC BY) 4.0 International. Estra licença permite que terceiros remixem, adaptem e criem a partir do trabalho publicado, atribuindo o devido crédito de autoria e publicação inicial neste periódico. Os autores têm autorização para assumir contratos adicionais separadamente, para distribuição não exclusiva da versão do trabalho publicada neste periódico (ex.: publicar em repositório institucional, em site pessoal, publicar uma tradução, ou como capítulo de livro), com reconhecimento de autoria e publicação inicial neste periódico.

\section{Publisher}

Universidade Federal de Santa Catarina. Programa de Pós-Graduação em Literatura. Publicação no Portal de Periódicos UFSC. As ideias expressadas neste artigo são de responsabilidade de seus/suas autores/as, não representando, necessariamente, a opinião dos/as editores/as ou da universidade.

\section{Histórico}

Recebido em: 30/10/2020

Aprovado em: 13/01/2021

Publicado em: 31/08/2021 